\title{
Prognostic Impact of let-7e MicroRNA and Its Target Genes in Localized High-Risk Intestinal GIST: A Spanish Group for Research on Sarcoma (GEIS) Study
}

\author{
Antonio Fernandez-Serra ${ }^{1}$, David S. Moura ${ }^{2}{ }^{(0}$, María Dolores Sanchez-Izquierdo ${ }^{3}$, \\ Silvia Calabuig-Fariñas ${ }^{4,5,6} \oplus$, Maria Lopez-Alvarez ${ }^{2}$, Andrea Martínez-Martínez ${ }^{1}$, \\ Irene Carrasco-Garcia ${ }^{2,7}$, Marta Ramírez-Calvo ${ }^{1}$, Elena Blanco-Alcaina ${ }^{2}$, Raquel López-Reig ${ }^{1}$, \\ Antonia Obrador-Hevia ${ }^{8,9}$ (D) Regina Alemany ${ }^{10}$, Antonio Gutierrez ${ }^{11}$, Nadia Hindi ${ }^{2,7}$ (D), \\ Andres Poveda ${ }^{12}$, Jose A. Lopez-Guerrero 1,13,*(D) and Javier Martin-Broto $2,7, * \mathbb{D}$ \\ 1 Laboratory of Molecular Biology, Fundación Instituto Valenciano de Oncología, 46009 Valencia, Spain; \\ afernandez@fivo.org (A.F.-S.); anmar59@upv.es (A.M.-M.); mramirezc@fivo.org (M.R.-C.); \\ rlopez@fivo.org (R.L.-R.) \\ 2 Institute of Biomedicine of Sevilla (IBIS, HUVR, CSIC, Universidad de Sevilla), 41013 Sevilla, Spain; \\ david.moura@usal.es (D.S.M.); marlopalv4@gmail.com (M.L.-A.); irenecg1990@gmail.com (I.C.-G.); \\ elena.blancoalcaina@gmail.com (E.B.-A.); nhindi@mustbesevilla.org (N.H.) \\ 3 Instituto de Investigación Sanitaria La Fe, 46026 Valencia, Spain; maria.d.sanchez@uv.es \\ 4 Molecular Oncology Laboratory, Fundación Investigación, Hospital General Universitario de Valencia, \\ 46014 Valencia, Spain; calabuix_sil@gva.es \\ 5 Centro de Investigación Biomédica en Red de Cáncer (CIBEROnc), 28029 Madrid, Spain \\ 6 Department of Pathology, Universitat de València, 46003 Valencia, Spain \\ 7 Medical Oncology Department, University Hospital Virgen del Rocio, 41013 Sevilla, Spain \\ 8 Group of Advanced Therapies and Biomarkers in Clinical Oncology, Institut d'Investigació Sanitària de les \\ Illes Balears (IdISBa-IUNICS), 07120 Palma de Mallorca, Spain; antonia.obrador@ssib.es \\ 9 Sequencing Unit, University Hospital Son Espases, 07120 Palma de Mallorca, Spain \\ 10 Department of Biology, Balearic Islands University, 07122 Palma de Mallorca, Spain; regina.alemany@uib.es \\ 11 Hematology Department, University Hospital Son Espases, 07120 Mallorca, Spain; \\ antoniom.gutierrez@ssib.es \\ 12 Medical Oncology Department, Fundación Instituto Valenciano de Oncología, 46009 Valencia, Spain; \\ apoveda@fivo.org \\ 13 Department of Basic Medical Sciences, School of Medicine, Catholic University of Valencia 'San \\ Vicente Martir', 46001 Valencia, Spain \\ * Correspondence: jalopez@fivo.org (J.A.L.-G.); jmartin@mustbesevilla.org (J.M.-B.)
}

Received: 11 August 2020; Accepted: 10 October 2020; Published: 14 October 2020

Simple Summary: For intestinal localized high-risk gastrointestinal stromal tumors (GIST) patients ${ }^{\prime}$ new molecular biomarkers are urgently needed for a more accurate prognosis. In our study, miRNA profiling analyses was planned to explore new molecular biomarkers with potential prognostic role in this clinical context. Our data, revealed that 39 microRNAs (miRNAs) were significantly deregulated when comparing patients with disease relapsed versus non-relapsed cases. The underexpression of a specific miRNA let-7e and the overexpression of 4 of its target genes $(A C V R 1 B, C A S P 3, C O L 3 A 1$ and COL5A2) correlated significantly with worse relapse-free survival. Overall, our results suggest that miRNA profiling is a potential molecular tool useful for a more accurate prognosis for intestinal localized high-risk GIST patients.

Abstract: MicroRNAs (miRNAs) are small non-coding RNAs that negatively regulate gene expression at the post-transcriptional level, and they have been described as being associated with tumor prognosis. Here, miRNA profiling was planned to explore new molecular prognostic biomarkers 
in localized intestinal high-risk GIST. Paraffin tumor blocks of 14 and 86 patients were used in the discovery and expansion sets, respectively. GeneChip miRNA v3.0 was employed to identify the miRNAs differentially expressed between relapsed and non-relapsed patient samples, which were validated in the expansion set, by qRT-PCR. RT2 Profiler PCR Array was used for the screening of let-7e targets. Expression levels were correlated with relapse-free survival and overall survival. In the discovery set, 39 miRNAs were significantly deregulated, let-7e and miR-550 being the most underexpressed and overexpressed miRNAs in the relapsed group, respectively. In the expansion set, the underexpression of let-7e or the overexpression of 4 of its target genes (ACVR1B, CASP3, COL3A1, and COL5A2) were statistically associated with worse relapse-free survival. The expression of let-7e and 4 of its target genes are potential prognostic biomarkers in high-risk localized intestinal GIST. The expression of these genes is a potential molecular tool useful for a more accurate prognosis in this subset of GIST patients.

Keywords: GIST; let-7e; prognostic biomarkers; caspase-3; miR-550

\section{Introduction}

Gastrointestinal stromal tumors (GISTs) are the most common mesenchymal neoplasms of the gastrointestinal tract. GISTs represent a morphological and biological continuum from incidentally discovered, $<10 \mathrm{~mm}$ nodules to large sarcomas [1]. GISTs represent a paradigmatic solid-tumor model for targeted therapy with 3 tyrosine-kinase inhibitors (TKI) registered for first [2], second [3] and third [4] lines in advanced disease and adjuvant Imatinib for high-risk localized GIST [5]. Despite this enormous therapeutic investigation on molecular targeted therapy in this entity, the risk classification for localized GIST patients still relies on clinical-pathological features such as mitotic count, size tumor location, and tumor rupture [6].

Risk classification of GISTs entails critical information in order to make decisions around adjuvant systemic treatment for these patients. Sometimes, overcounting or undercounting just one mitotic figure can imply 3 years of adjuvant treatment with imatinib. Moreover, those cases for which neoadjuvant treatment is recommended usually have insufficient tumor tissue in the core-biopsy for an adequate mitotic count, making it difficult to establish the risk. In view of the above and in the context of a tumor model for targeted therapies, molecular prognostic variables might be instrumental for a more accurate prognosis delimitation.

Few studies have explored the prognostic relevance of genomic alterations, suggesting the potential relevance of KIT and PDGFRA genotyping in prognosis in localized GIST. More specifically, several authors have pointed out the prognostic role of deletion type mutations involving 557 and/or 558 codons of exon 11 in KIT [7,8]. Two authors have demonstrated in larger series that it is feasible to incorporate genotype information in risk classification since patients harboring mutations involving 557 and/or 558 had significantly more risk of recurrence in the intermediate subgroup $[9,10]$. Nevertheless, the prognostic impact of these mutations is restricted only in gastric location. For intestinal localized GIST, no molecular biomarker has been shown to be a convincing prognostic factor. Hence, there is an unmet need for molecular biomarkers for intestinal localized high-risk GIST.

MicroRNAs (miRNAs) encompass a family of more than 2500 small non-coding RNA that negatively regulate gene expression at post-transcriptional level. Based on the stability that they exhibit in formalin-fixed paraffin-embedded (FFPE) blocks [11], miRNAs were found appropriate to be explored in old archival paraffin blocks of GIST, before the adjuvant imatinib time period. With the aim of exploring new molecular biomarkers with a potential prognostic role in localized GIST, a miRNA profiling analysis was planned in the context of intestinal localized high-risk GIST patients. 


\section{Results}

\subsection{Discovery Set}

Fourteen patients, corresponding to cases of high-risk intestinal GIST fitting the inclusion criteria, were analyzed for the miRNA screening. There were 8 cases with relapse and 6 without tumor relapse. The median size was $11 \mathrm{~cm}(5-25 \mathrm{~cm})$ and the median mitotic count was 12 mitoses per $50 \mathrm{hpf}$. The demographics of this series is shown in Table 1.

Table 1. Series demographics.

\begin{tabular}{|c|c|c|c|}
\hline Clinical and Pathological Parameters & $\begin{array}{l}\text { Discovery Set } \\
\qquad N=14\end{array}$ & $\begin{array}{l}\text { Validation Set } \\
\qquad N=86\end{array}$ & $\begin{array}{c}\text { Validation Set } \\
\text { Small-Intestine Series } \\
\qquad N=75\end{array}$ \\
\hline Sex: male/female (\%) & $7(50 \%) / 7(50 \%)$ & $52(61 \%) / 34(39 \%)$ & $47(63 \%) / 28(37 \%)$ \\
\hline Median follow-up (months) & $85(0-198)$ & $73(0-253)$ & $76(0-253)$ \\
\hline Median mitotic count (/50 HPF) (range) & $13(0-133)$ & $10(0-133)$ & $10(0-133)$ \\
\hline $\begin{array}{c}\text { Primary tumor site: } \\
\text { Small-intestine }(\%) \\
\text { Rectum }(\%) \\
\text { Colon }(\%) \\
\text { Omentum }(\%) \\
\text { Peritoneum } \\
\text { Others }\end{array}$ & $\begin{array}{c}14(100 \%) \\
0(0 \%) \\
0(0 \%) \\
0(0 \%) \\
0(0 \%) \\
0(0 \%)\end{array}$ & $\begin{array}{c}75(87 \%) \\
4(5 \%) \\
1(1 \%) \\
1(1 \%) \\
3(4 \%) \\
2(2 \%)\end{array}$ & $\begin{array}{c}75(100 \%) \\
0(0 \%) \\
0(0 \%) \\
0(0 \%) \\
0(0 \%) \\
0(0 \%)\end{array}$ \\
\hline $\begin{array}{c}\text { Relapse: } \\
-\quad \text { Yes } \\
- \text { No }\end{array}$ & $\begin{array}{l}8(58 \%) \\
6(42 \%)\end{array}$ & $\begin{array}{c}58(67 \%) \\
28(330 \%)\end{array}$ & $\begin{array}{l}49(65 \%) \\
26(35 \%)\end{array}$ \\
\hline $\begin{array}{c}\text { Genotype: } \\
\text { - Wild type } \\
\text { - } \quad \text { KIT mutation } \\
\text { - PDGFRA mutation } \\
\text { - Not available }\end{array}$ & $\begin{array}{c}4(29 \%) \\
9(64 \%) \\
1(7 \%) \\
0(0 \%)\end{array}$ & $\begin{array}{c}18(20 \%) \\
52(61 \%) \\
4(5 \%) \\
12(14 \%)\end{array}$ & $\begin{array}{l}17(23 \%) \\
47(63 \%) \\
2(2 \%) \\
9(12 \%)\end{array}$ \\
\hline $\begin{array}{cc}\text { KIT mutation: } \\
-\quad \text { Exon 11 } \\
-\quad \text { Exon } 9 \\
-\quad \text { Exon } 13\end{array}$ & $\begin{array}{l}6(67 \%) \\
2(22 \%) \\
1(11 \%)\end{array}$ & $\begin{array}{l}44(85 \%) \\
7(14 \%) \\
1(1 \%)\end{array}$ & $\begin{array}{l}40(85 \%) \\
6(13 \%) \\
1(2 \%)\end{array}$ \\
\hline
\end{tabular}

The microRNA expression profiling resulted in 39 miRNAs significantly $(p \leq 0.05 ; \mathrm{FC} \geq 2)$ deregulated between relapsed and non-relapsed groups. The two main discriminating miRNA between both groups were lethal-7e (let-7e; underexpressed, FC $=-1163.99, p<0.0001$ ) and miR-550 (overexpressed, FC = 204.173, $p<0.0001$ ), when comparing relapsed with non-relapsed patients. Other relevant down-regulated miRNAs in relapsed cases were miR-17 (FC $=-861.879, p<0.0001)$, miR-195 $(\mathrm{FC}=-785.334, p<0.0001)$ and $m i R-143(\mathrm{FC}=-627.526, p<0.0001)$, while $\mathrm{miR}-1184(\mathrm{FC}=184.493$, $p<0.0001)$ was up-regulated. However, all those miRNAs presented a lower FC in absolute terms than the selected ones. Within the relapsing cases, the three with the worst prognosis (so-called relapse out group) clustered together (Figure 1).

The prognostic value of both, let-7e and miR-550 was validated by qRT-PCR, confirming its downregulation $(\mathrm{FC}=0.6294)$ and up-regulation $(\mathrm{FC}=18.0421)$, respectively (Figure $\mathrm{S} 1)$. 
a

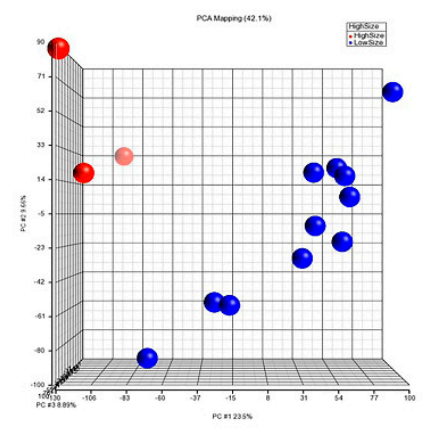

b

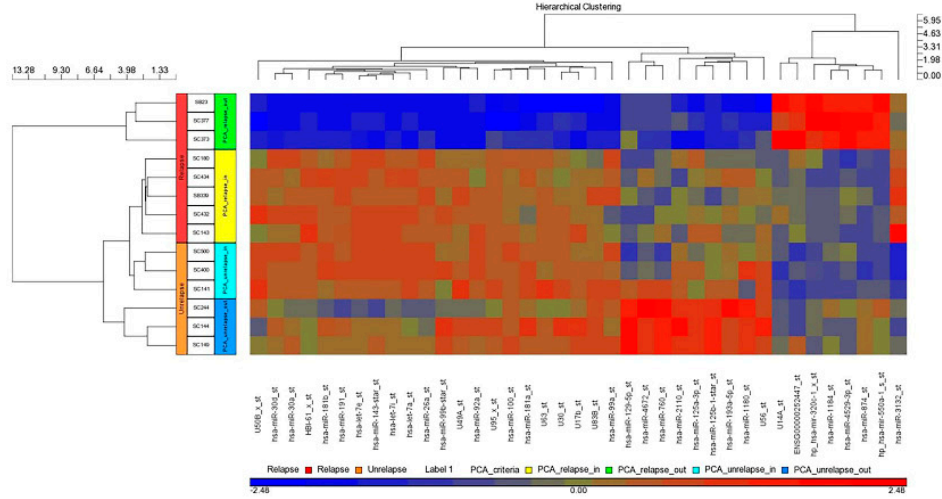

Figure 1. (a) Principal component analysis of the 14 samples included in the discovery series. Whole expression of the miRNAs included in the microarray showed a good discriminant power clustering the samples according to its prognosis. (b) Clustering and HeatMap considering de-regulated genes in the microarray.

\subsection{Expansion Set}

A subset of 86 localized high-risk intestinal GIST patients, meeting the inclusion criteria, were selected as the expansion set. With a median follow-up of 117 months, 58 patients had a recurrence event $(67.4 \%)$. Median size and mitoses of the primary tumor were $10 \mathrm{~cm}$ and 10/50 hpf, respectively. The actuarial 5-year RFS was 33\% in this validation series. The most relevant demographics are depicted in Table 1. The majority of cases were diagnosed with GIST from 1995 to 2000. The univariate analyses for RFS showed statistically significant differences for mitotic count ( $\leq 10$ vs. $>10$ mitoses per $50 \mathrm{hpf}$ ), tumor location (small intestine vs colorectal), and let-7e expression (levels higher or lower than the ROC cutoff). The median RFS was 98.2 (95\% CI 0-218.6) and 20 (95\% CI 13.5-26.5) months for cases $\leq 10$ and $>10$ mitoses per $50 \mathrm{hpf}$, respectively, with $p$-value $<0.001$. It was 33.4 (95\% CI 23.7-43.1) and 13.4 (95\% CI 1.8-25) months for small intestine and colorectal cases respectively with a $p$-value of 0.001 , and 41.1 (95\% CI 18.2-64) vs. 25 (95\% CI 18.2-64) months for cases with let-7e expression levels above and below the ROC cutoff, respectively, with a $p$-value of 0.012 . The four selected target genes of let-7e (Figure 2 and Table S1) showed prognostic relevance in the univariate analysis, following the ROC cutoff.

A

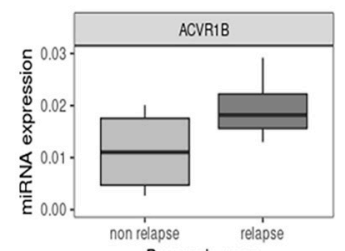

Prognosis group

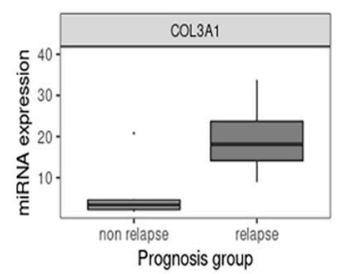

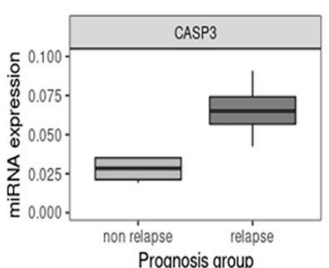

Prognosis group

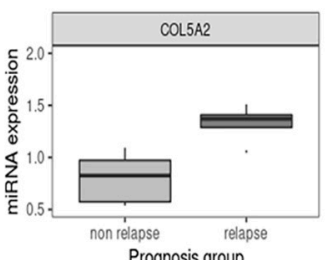

B

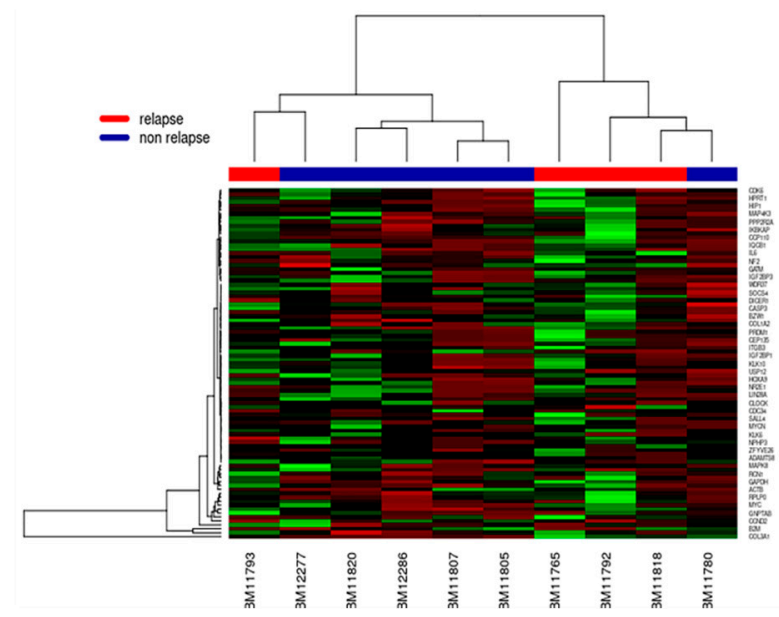

Figure 2. (A) Boxplot of the 4 mRNAs showing differential expression between relapse and relapse-free 
groups. The four genes show significant differential expression: ACVR1B $(p=0.0493)$, CASP3 $(p=0.0029)$, COL3A1 $(p=0.039)$, COL5A2 $(p=0.015)$. (B) Heatmap and dendogram of the 84 mRNAs screened as putative targets of let-7e.

Thus, the RFS for values above and below the ROC cutoff were as follows: for ACVR1B gene, 28.9 (95\% CI 16.8-41.1) months and 43.6 (95\% CI 8.1-79.1) months with a $p$-value of 0.023; for the COL3A1 gene, 21.3 (95\% CI 7.5-35.2) months and 39.5 (95\% CI 26.9-52.2) months with $p$-value of 0.012; for COL5A2 gene, 14.1 (95\% CI 2.4-25.7) months and 35.5 (95\% CI 23.9-47.1) months, with $p$-value of 0.003 and for CASP3 gene, 26.5 (95\% CI 16.1-37) months and 39.5 (95\% CI 4-75.1) months with $p$-value 0.018. The complete information of univariate analysis is represented in Table 2.

Table 2. Univariate analyses.

\begin{tabular}{|c|c|c|c|c|}
\hline \multirow[t]{2}{*}{ Factor } & \multicolumn{4}{|c|}{ Whole Series } \\
\hline & $\begin{array}{l}\text { Median RFS } \\
\text { (CI 95\%) }\end{array}$ & $p$ & $\begin{array}{l}\text { Median OS } \\
\text { (CI 95\%) }\end{array}$ & $p$ \\
\hline $\begin{array}{l}\text { Age: } \\
-\quad 0-60 \\
-\quad>60\end{array}$ & $\begin{array}{l}26.5(15.1-37.9) \\
31.7(22.7-40.8)\end{array}$ & 0.34 & $\begin{array}{c}155(\text { NA) } \\
\text { NR }\end{array}$ & 0.4 \\
\hline $\begin{array}{c}\text { Sex: } \\
\text { - } \quad \text { Male } \\
\text { - } \quad \text { Female }\end{array}$ & $\begin{array}{l}31.7(24.6-38.8) \\
32.2(4.5-59.8)\end{array}$ & 0.61 & $\begin{array}{c}155.9(43.4-268.4) \\
\text { NR }\end{array}$ & 0.62 \\
\hline $\begin{array}{c}\text { Size: } \\
-\quad 0-10 \\
-\quad>10\end{array}$ & $\begin{array}{l}32.2(15.8-48.5) \\
27.3(13.3-41.2)\end{array}$ & 0.075 & $\begin{array}{c}\text { NR } \\
73.4(52.9-93.9)\end{array}$ & 0.001 \\
\hline $\begin{array}{l}\text { Mitosis: } \\
-\quad 0-10 \\
-\quad>10\end{array}$ & $\begin{array}{l}98.2(0-218.6) \\
20(13.5-26.5)\end{array}$ & $<0.001$ & $\begin{array}{c}\text { NR } \\
78(37.7-118.2)\end{array}$ & 0.13 \\
\hline $\begin{array}{c}\text { Critical mutation: } \\
- \text { Yes } \\
- \text { No }\end{array}$ & $\begin{array}{c}32.2(16.2-48.1) \\
31.7(21.4-42)\end{array}$ & 0.64 & $\begin{array}{c}\text { NR } \\
155.9(36.7-275.2)\end{array}$ & 0.8 \\
\hline $\begin{array}{l}\text { Tumor location: } \\
\text { - Small-intestine } \\
\text { - Other }\end{array}$ & $\begin{array}{c}33.4(23.7-43.1) \\
13.4(1.8-25)\end{array}$ & 0.001 & $\begin{array}{c}155.9(\mathrm{NA}) \\
77.6(16.2-139.1)\end{array}$ & 0.22 \\
\hline $\begin{array}{c}\text { let-7e expression *: } \\
-\quad<131.42 \\
-\quad>131.42\end{array}$ & $\begin{array}{l}25(18.2-31.8) \\
41.1(18.2-64)\end{array}$ & 0.012 & $\begin{array}{c}90.2(73.5-106.9) \\
\text { NR }\end{array}$ & 0.32 \\
\hline $\begin{array}{c}\text { miR550 expression *: } \\
-\quad<4063.67 \\
-\quad>4063.67\end{array}$ & $\begin{array}{l}31.9(21.1-42.6) \\
29.9(20.7-39.2)\end{array}$ & 0.136 & $\begin{array}{l}155.9 \text { (NA) } \\
\text { NR }\end{array}$ & 0.55 \\
\hline $\begin{array}{c}\text { ACVR1B expression *: } \\
-\quad<0.000629 \\
-\quad>0.000629\end{array}$ & $\begin{array}{c}43.6(8.1-79.1) \\
28.9(16.8-41.1)\end{array}$ & 0.023 & $\begin{array}{c}\text { NR } \\
117.3(42.4-192.2)\end{array}$ & 0.54 \\
\hline $\begin{array}{c}\text { CASP3 expression *: } \\
-\quad<0.000769 \\
-\quad>0.000769\end{array}$ & $\begin{array}{c}39.5(4-75.1) \\
26.5(16.1-37)\end{array}$ & 0.018 & $\begin{array}{c}\text { NR } \\
155.9(23.2-288.6)\end{array}$ & 0.71 \\
\hline $\begin{array}{c}\text { COL3A1 expression *: } \\
-\quad<0.671380 \\
-\quad>0.671380\end{array}$ & $\begin{array}{l}39.5(26.9-52.2) \\
21.3(7.5-35.2)\end{array}$ & 0.012 & $\begin{array}{c}\text { NR } \\
61.8(23.9-99.7)\end{array}$ & 0.037 \\
\hline $\begin{array}{c}\text { COL5A2 expression *: } \\
-\quad<0.014649 \\
-\quad>0.014649\end{array}$ & $\begin{array}{c}35.5(23.9-47.1) \\
14.1(2.4-25.7)\end{array}$ & 0.003 & $\begin{array}{c}N R \\
81.1(0-167.6)\end{array}$ & 0.26 \\
\hline
\end{tabular}


Table 2. Cont.

\begin{tabular}{|c|c|c|c|c|}
\hline \multirow[t]{2}{*}{ Factor } & \multicolumn{4}{|c|}{ Whole Series } \\
\hline & $\begin{array}{l}\text { Median RFS } \\
\text { (CI 95\%) }\end{array}$ & $p$ & $\begin{array}{l}\text { Median OS } \\
\text { (CI 95\%) }\end{array}$ & $p$ \\
\hline $\begin{array}{l}\text { Age: } \\
-\quad 0-60 \\
-\quad>60\end{array}$ & $\begin{array}{c}32.4(15.1-49.6) \\
35.5(6.2-64.9)\end{array}$ & 0.38 & $\begin{array}{c}155 \text { (NA) } \\
\text { NR }\end{array}$ & 0.76 \\
\hline $\begin{array}{c}\text { Sex: } \\
-\quad \text { Male } \\
-\quad \text { Female }\end{array}$ & $\begin{array}{l}31.9(24.3-39.6) \\
50.5(9.8-91.1)\end{array}$ & 0.5 & $\begin{array}{c}155.9(22.7-289.1) \\
\text { NR }\end{array}$ & 0.75 \\
\hline $\begin{array}{c}\text { Size: } \\
-\quad 0-10 \\
-\quad>10\end{array}$ & $\begin{array}{c}36.9(5.5-68.3) \\
28.9(11.4-46.5)\end{array}$ & 0.061 & $\begin{array}{c}\text { NR } \\
73.4(49.4-97.4)\end{array}$ & 0.005 \\
\hline $\begin{array}{l}\text { Mitosis: } \\
-\quad 0-10 \\
-\quad>10\end{array}$ & $\begin{array}{c}161.2(2.7-319.6) \\
20.8(15.4-26.1)\end{array}$ & $<0.001$ & $\begin{array}{c}\text { NR } \\
90.2(36.3-144)\end{array}$ & 0.14 \\
\hline $\begin{array}{c}\text { Critical mutation: } \\
- \text { Yes } \\
- \text { No }\end{array}$ & $\begin{array}{l}32.4(10.8-53.9) \\
32.2(16.2-48.1)\end{array}$ & 0.22 & $\begin{array}{c}N R \\
155.9(36.7-275.2)\end{array}$ & 0.63 \\
\hline $\begin{array}{l}\text { Tumor location: } \\
\text { - Small-intestine } \\
\text { - Other }\end{array}$ & $N A$ & & $N A$ & \\
\hline $\begin{array}{c}\text { Let-7e expression *: } \\
-\quad<131.42 \\
-\quad>131.42\end{array}$ & $\begin{array}{c}26.5(20.6-32.5) \\
98.2(0-225.1)\end{array}$ & 0.003 & $\begin{array}{l}90.3 \text { (NA) } \\
\text { NR }\end{array}$ & 0.38 \\
\hline $\begin{array}{c}\text { miR550 expression *: } \\
-\quad<4063.67 \\
-\quad>4063.67\end{array}$ & $\begin{array}{l}35.5(24.8-46.3) \\
32.2(25.9-38.4)\end{array}$ & 0.096 & $\begin{array}{c}155.9 \text { (NA) } \\
\text { NR }\end{array}$ & 0.46 \\
\hline $\begin{array}{c}A C V R 1 B \text { expression *: } \\
-\quad<0.000629 \\
-\quad>0.000629\end{array}$ & $\begin{array}{l}58.2(0-128.6) \\
30(22.7-37.2) \\
\end{array}$ & 0.028 & $\begin{array}{c}N R \\
155.9(50.7-261.1)\end{array}$ & 0.57 \\
\hline $\begin{array}{c}\text { CASP3 expression *: } \\
-\quad<0.000769 \\
-\quad>0.000769\end{array}$ & $\begin{array}{l}50.5(0-106.7) \\
21.3(7.6-35.1)\end{array}$ & 0.008 & $\begin{array}{c}\text { NR } \\
72.1(0-150.7)\end{array}$ & 0.34 \\
\hline $\begin{array}{c}\text { COL3A1 expression *: } \\
-\quad<0.671380 \\
-\quad>0.671380\end{array}$ & $\begin{array}{c}39.5(16.4-62.7) \\
25(17.7-32.4)\end{array}$ & 0.03 & $\begin{array}{c}N R \\
61.8(30.2-93.5)\end{array}$ & 0.053 \\
\hline $\begin{array}{c}\text { COL5A2 expression *: } \\
-\quad<0.014649 \\
-\quad>0.014649\end{array}$ & $\begin{array}{c}39.5(26.6-52.4) \\
20.3(8.4-32.1)\end{array}$ & 0.002 & $\begin{array}{c}\text { NR } \\
81.1(0-168.9)\end{array}$ & 0.17 \\
\hline
\end{tabular}

* Optimal cutoff calculated using ROC curves.

Additionally, in order to replicate more precisely the discovery set and to select a more homogeneous population, the analysis was replicated specifically in the 75 small intestine cases. The same prognostic factors in the whole series exhibited a statistically significant difference for RFS in the small intestine series, showing greater differences between prognostic groups (Table 2 and Figure 3). The prognostic role of $m i R-550$ was not confirmed in the expansion set (Figure S2), neither in the whole series nor in the small intestine subset. In the whole series, cases with let-7e overexpression and low expression of each one of the let-7e target genes had significantly better RFS (Figure S3). 

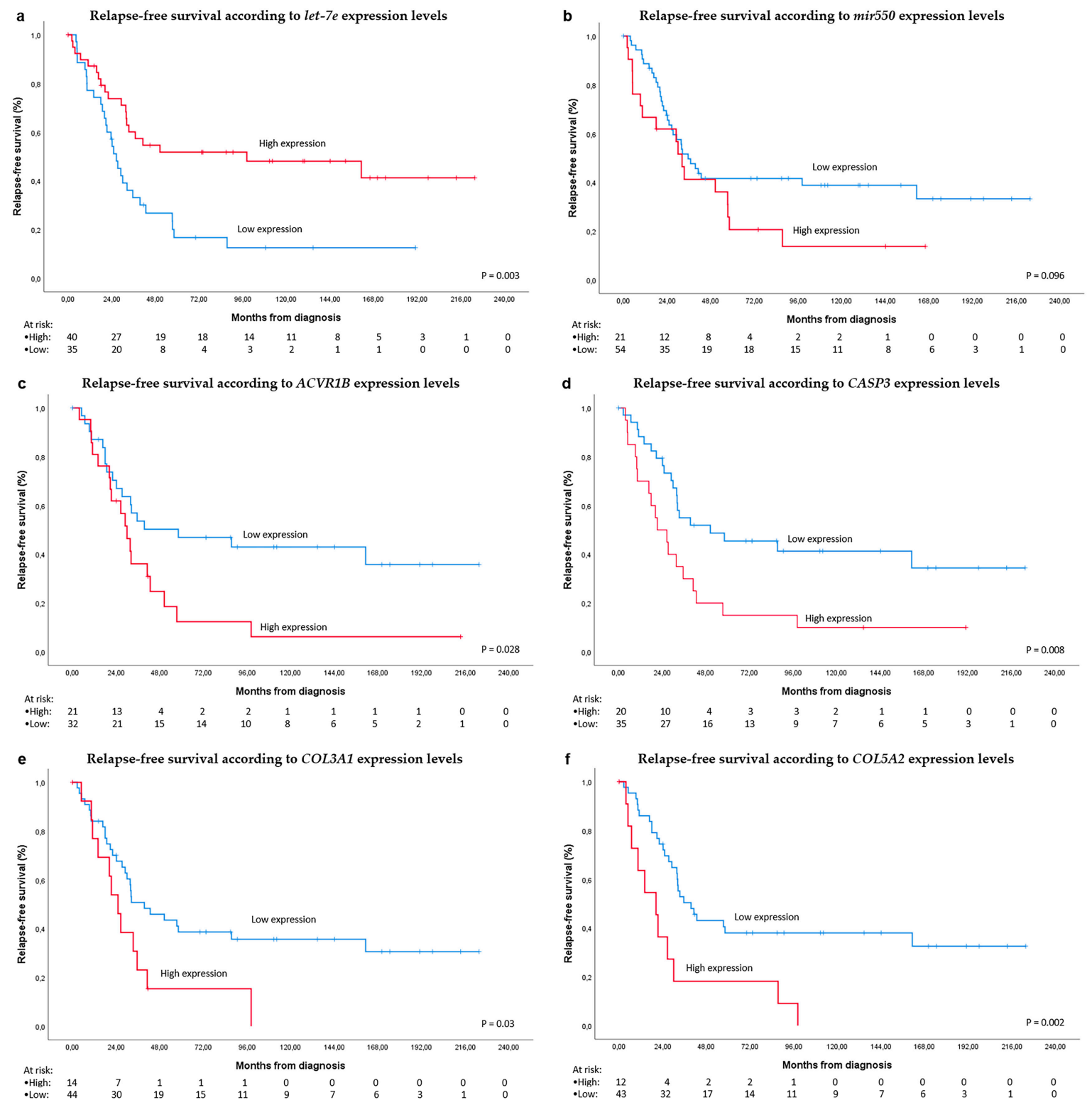

Figure 3. Survival analyses. (a) relapse-free survival (RFS) according to let-7e expression levels in the small intestine validation set; (b). RFS according to MIR550 expression levels; (c) RFS according to ACVR1B expression levels; (d) RFS according to CASP3 expression levels; (e) RFS according to COL3A1 expression levels; (f) RFS according to COL5A2 expression levels. Cutoff points were calculated with the ROC curve, separating into High and Low expression groups, when the expression levels were above or below the cutoff, respectively.

In the multivariate analysis, mitotic count higher than 10 mitoses per $50 \mathrm{hpf}$ (HR 3.5; 95\% CI 1.7-7.1; $p=0.001$ ) and CASP3 mRNA expression above the ROC cutoff (HR 2.5; 95\% CI 1.2-4.9; $p=0.010$ ) showed independent worse prognosis for RFS. Likely, in the small intestine series these factors were the only independent prognostic variables: mitotic count higher than 10 mitoses per $50 \mathrm{hpf}$ (HR 3.2; 95\% CI 1.5-6.7; $p=0.002$ ) and CASP3 mRNA expression above the ROC cutoff (HR 2.6; 95\% CI 1.3-5.3; $p=0.008$ ). If let-7e target genes are not included, then let-7e expression (HR $0.4 ; 95 \%$ CI $0.2-0.8 ; p=0.005$ ) and mitotic count (HR 2.5; 95\% CI 1.3-5.1; $p=0.01$ ) remained as independent prognostic predictors. The mitotic count did not correlate with let-7e expression $(p=0.16)$.

Only size showed a prognostic role in the univariate analysis for overall survival from the time of diagnosis. Nevertheless, the fact that imatinib has been available since 2002 and some cases had 
recurrences earlier than this date could induce bias in the overall survival analysis, confirming the use of relapse events as an optimal surrogate for survival in this series. Besides that, a subset of 77 patients with metastatic progression ( 58 recurred patients from this localized series along with 19 intestinal GIST with metastatic presentation) was considered for a sub-analysis. Among those, there were 56 cases that received imatinib. The univariate analysis screened let-7e and gene expression of let-7e targets as prognostic factors for progression-free survival (PFS) from the time of imatinib initiation. Patients with let-7e expression above and below the ROC cutoff value had progression-free survival of 69.8 (95\% CI, 51.3-88.3) and 25.4 months (95\% CI, 21.1-29.6), respectively, with a $p$-value of 0.098 . Among the analyzed target genes of let-7e, ACVR1B, CASP3, and COL5A2 showed the same trend observed in the relapse-free survival analysis, a shorter imatinib PFS for values above the ROC cutoff value (Table S2). These differences did not reach statistical significance, probably in relation to the lower number of cases, since only in 33 cases was the RNA expression of these target genes available for the subset with advanced disease treated with imatinib.

\section{Discussion}

In this high-risk series of localized, completely resected intestinal GIST and imatinib adjuvant naïve, let-7e was the most significant under-expressed miRNA in the worse prognostic subset of the discovery set. Its prognostic value was validated in the expansion series, showing an independent prognostic value for RFS. let-7 constitutes a family of miRNA with 13 members encoding 9 mature miRNA that control developmental timing and differentiation [12]. Even when let-7 has been described as acting as an oncogene [13], in the vast majority of cases let-7 members also act as tumor suppressor genes $[14,15]$. Interestingly, let-7 is not only found to be decreased in a plethora of tumors, but the underexpression of several members of this family have been associated with poor tumor prognosis $[16,17]$. Concerning the mechanisms of action linked with prognosis, let-7 has been involved in several signaling pathways, which could explain its prognostic implication. Suppression of oncogene HMGA2 [18], inhibition of stemness phenotype [19,20], reduction of phosphorylation of carcinogenic signaling as AKT [21], influence in immunomodulation [22], suppression of proliferation [23,24] and control of invasion/migration $[25,26]$ are among the different mechanisms by which let- 7 can modulate tumor prognosis.

The screening for putative mRNA targets of let-7e, revealed that 4 genes (ACVR1B, CASP3, COL3A1, and COL5A2) had a significant prognostic impact on RFS, in both the discovery and expansion sets. Overexpression of each of these genes was related to underexpression of let-7e and with a worse risk of RFS in this intestinal localized GIST series. To the best of our knowledge, this is the first time that let-7e and these putative target genes have been related to prognosis in GIST.

Specifically, let-7e has been related to migration and invasion in some tumors. In breast cancer, let-7e negatively regulates Myeloid Zinc Finger 1 (MZF1), a transcription factor that ultimately upregulates lysosomal cathepsins B and L in the context of ErbB2 positive breast cancer [27]. In papillary thyroid carcinoma, let-7e inhibits migration and invasion through the downregulation of HMGB1 [28]. Similarly, two of the significantly dysregulated let-7e target genes in our study, COL3A1 and COL5A2, have relevant roles in migration and invasion, as has been described in some tumors. In bladder carcinoma, COL3A1 has been implicated in tumor invasion by regulating the MAPK signaling pathway [29], and in nasopharyngeal carcinoma, COL3A1 was identified as the only target of miR-29b in relation to migration and invasion [30]. Moreover, overexpression of COL5A2 has been related to worse prognosis with potential association with invasion and dissemination in bladder carcinoma [31], or in osteosarcoma, as an effector of NKX2-2 [32], among others.

Overexpression of $A C V R 1 B$, a key receptor of bone morphogenetic proteins (BMPs) and an important regulator of the BMP/Wnt signaling pathway and, therefore, for cancer stem cells, was associated with clinically aggressive and poor survival in hepatocellular carcinoma [33]. The implication of $A C V R 1 B$ and BMP in cancer has exhibited a dual function according to different cancer cell types or different BMP ligands, promoting or preventing critical cancer hallmarks such as stemness, migration, 
or proliferation [34]. Protein expression of Caspase-3, either the cleaved fraction or total protein, was associated with poor prognosis in patients with moderately-differentiated carcinoma of the tongue [35]. The expression of CASP3 was observed to be elevated in some tumors [36] but decreased in others [37], maybe indicating that its expression and its prognostic influence could be largely influenced by tumor and microenvironment context. It could be speculated that caspase- 3 overexpression is an epiphenomenon, at least in tumors with substantial apoptotic activity, since dying cells can release mitogens to promote the so-called apoptosis-induced proliferation [38]. However, pro-apoptotic proteins, such as BAX, are downregulated in GIST, while anti-apoptotic proteins, such as BCL2 members and inhibitor of apoptosis (IAP) proteins, are commonly upregulated in GIST [39]. Therefore, it seems that it is not easy to harmonize the finding that CASP3 overexpression, which is related to worse RFS in localized intestinal GIST, with the inhibition of apoptosis seen in GIST. It could be assumed that CASP3 failed to become activated, in the GIST context, to participate in the programmed cell death. Nevertheless, in other tumors, the expression level of cleaved caspase 3 did not correlate with spontaneous apoptosis [40], and the overexpression of cleaved caspase 3, not only of the procaspase-3, showed worse disease-free survival [35] Thus, despite the fact that dysregulation of apoptosis is detected in GIST by different means [41,42], it is still not possible to clarify the fine-tuning among different regulators of apoptosis to properly explain the apparent discordance between higher CASP3 expression and worse prognosis or apoptosis inhibition in the context of localized intestinal GIST patients. Some miRNAs have been associated with apoptosis dysregulation in GIST, with MIR221/MIR222 having been related to oncogenic GIST development in two of these studies [43,44]. Our group had reported that over-expression of MIR221/MIR222 was related to worse survival prognosis in a subset of kit negative GIST patients [45].

A weakness of this study, in part owing to the old archived samples, is that genotyping was not feasible in up to $14 \%$ of the series. The presence of mutations involving codons 557 and/or 558 in exon 11 of the gene KIT, did not exhibit prognostic impact in this series. This is in line with a large study that demonstrated these mutations had a prognostic impact only in gastric GISTs [9]. The absence of a functional validation of these results in GIST in vitro experiments is another limitation of this study.

Profiling of miRNAs was preferred over other types of profiling, such as mRNA, due to the higher stability shown by miRNAs between paraffin-embedded blocks and fresh tumor-sample analysis. In our series, archived paraffin blocks were used from cases not receiving adjuvant imatinib, meaning that the majority of them were previous to 2005.

\section{Materials and Methods}

\subsection{Study Design, Patients, and Samples}

Patients with the following inclusion criteria were selected from the GEIS registry: localized intestinal GIST, classified in accordance with Miettinen criteria as high-risk, having not received neoor adjuvant imatinib, absence of second primary tumor, and confirmation of no tumor abdominal rupture. Procedures were performed in accordance with guidelines established by the hospital's Ethics Committee and the study was approved by Institutional Review Boards of the university hospitals Virgen Macarena-Virgen del Rocío, on 31 May 2016.

\subsection{Discovery Set}

RNA Isolation and Microarray Analysis

For the miRNA screening, 14 cases corresponding to patients with high-risk intestinal GIST, which met the inclusion criteria, were analyzed. For the screening of miRNA that discriminates between samples of relapsed and non-relapsed high-risk intestinal GIST, a GeneChip miRNA v3.0 (Affymetrix; Santa Clara, CA, USA) was used. One representative formalin-fixed and paraffin-embedded (FFPE) block was identified from each case, and 5 to $10-\mu \mathrm{m}$ thick sections were obtained for 
RNA extraction using the miRNeasy FFPE ${ }^{\circledR}$ kit (Qiagen; Hilden, Germany), according to the manufacturer's instructions.

RNA purity and concentration were evaluated spectrophotometrically using NanoDrop ND-2000 (ThermoFisher Scientifics; Waltham, MA, USA). The absorbance 260/280 ratio was greater than 1.77 in all cases, whereas the Absorbance 260/230 ratio was between 1.6 and 2.05.

Quality and related size of total and small RNA were assessed by the microfluidics-based platform Agilent 2100 Bioanalyzer (Agilent; Santa Clara, CA, USA) with two chips: Agilent RNA 6000 Nano Kit for total RNA and Agilent Small RNA kit for low molecular weight RNA. In the first approach, the RIN score ranged from 1.90 to 2.50, while the other kit showed RIN values between 2.40 and 2.60. Electropherograms were visualized with the Agilent 2100 Expert software, including data collection, peak detection, and interpretation of the different profiles. All samples showed similar integrity profiles. FFPE extracted RNA has low integrity, ranging from 200 to $600 \mathrm{bp}$, but it is acceptable for non-coding RNA studies due to their small size.

For microarray analysis, 600 ng of total RNA was labeled using a FlashTag HSR RNA labeling kit (Genisphere; Hatfield, PA, USA) and hybridized to the GeneChip miRNA 3.0 Array (Affymetrix), following the manufacturer's instructions. This version contains 19,913 probesets, including 5818 human premature miRNAs, cajal body associated RNA (scaRNA), small nuclear organizers (snoRNA), and mature miRNA. The GeneChip $\AA S c a n n e r 30007 G$ System and reagents from Affymetrix were used to hybridize, wash, stain, and scan the arrays. The hypothesis contrasts were made with an ANOVA test and adjusted $p$-value using the false discovery rate adjustment set to FDR $<0.5$ was used as significant. Normalization and statistical analysis were performed with Partek Genomic Suite 6.6 software (Partek; St. Louis, MO, USA), and technical validation of differentially expressed miRNAs was conducted using qRT-PCR.

\subsection{Expansion Set}

Selection criteria for the expansion set were the same as described above: intestinal GIST, classified in accordance to Miettinen criteria as high-risk, having not received neo- or adjuvant imatinib, absence of second primary tumor and confirmation of no abdominal tumor rupture. Patients had to be followed-up with scheduled CT scans by physicians of the GEIS network. Sections were obtained for RNA extraction using the RecoverAll Total RNA Extraction kit (Ambion; Austin, TX, USA). The expression of miRNAs was determined by means of qRT-PCR, using specific Taq-Man probes. miRNAs expression levels were categorized as above or below median values. Kaplan-Meier and log-rank tests were used for time-to-event variables with RFS, being the clinical endpoint.

\subsubsection{Quantitative RT-PCR for miRNA Quantification}

A biological validation was carried out on the expansion set $(n=86)$. For these cases, one representative block was selected and $3 \times 20-\mu \mathrm{m}$-thick sections were cut. RNA was isolated using the RecoverAll ${ }^{\mathrm{TM}}$ Total Nucleic Acid Isolation Kit for FFPE (Ambion), according to the manufacturer's instructions. RNA concentration was measured in a NanoDrop-1000 spectrophotometer (ThermoFisher Scientific, Waltham, MA, USA) absorbance 260/280 and 260/230 ratios were measured to assess the quality of the samples.

Reverse transcription was performed from $200 \mathrm{ng}$ of total RNA using the MicroRNA Reverse Transcription $\mathrm{Kit}^{\circledR}{ }^{\circledR}$ (Applied Biosystems; Foster City, CA, USA), according to the manufacturer's instructions.

The expression levels of the studied miRNA were determined by means of real-Time PCR using the following TaqMan miRNA assays (Applied Biosystems): let-7e (RT:002406), miR-550 (001544), in a 7500 Fast instrument (Applied Biosystems). RNU-44 (TM1094) and RNU48 (TM1006) were used as housekeeping genes. 


\subsubsection{Screening of mRNA Targets of let-7e}

The screening for putative mRNA targets of let-7e was performed with a specific RT2 Profiler PCR Array PAHS-6008Y (Qiagen) according to the manufacturer's instructions. miRNAs were selected by the manufacturer (Qiagen) according to biological or bioinformatic evidence. Besides, mRNA targets have been characterized as let-7e targets in public databases such as miR-DB using its own algorithm [46,47]. Each array contains 84 target genes plus 5 housekeeping genes. Briefly, an initial reverse transcription reaction was performed. The quantitative real-time PCR interrogating 84 genes previously validated as human targets of let-7 was used (Appendix A). This screening was carried out in ten samples previously used in the biological validation of the differentially-expressed miRNA expression, of which 4 correspond to relapsing samples. For this analysis, samples with optimum quality were chosen from among the biological validation set.

\subsubsection{Quantitative RT-PCR for the Validation of mRNA Targets}

The expression levels of the genes selected in the mRNA target screening of let-7 were measured by means of qRT-PCR using the following TaqMan RNA assays (Applied Biosystems): ACVR1B (Hs00244715_m1), CASP3 (Hs00234387_m1), COL3A1 (Hs00943809_m1), and COL5A2 (Hs00893878_m1). While B2M (Beta-2-microglobulin; Hs99999907_m1) and GAPDH (Hs00266705_g1) were used as housekeeping genes for data normalization. A 7500 Fast instrument (Applied Biosystems) was used. After data normalization, the relative expression of the genes was evaluated, applying the $2^{-\Delta \Delta C t}$ method for the Fold Change (FC) calculation. Figure 4 outlines all the above-mentioned steps in search of biomarkers in this study.

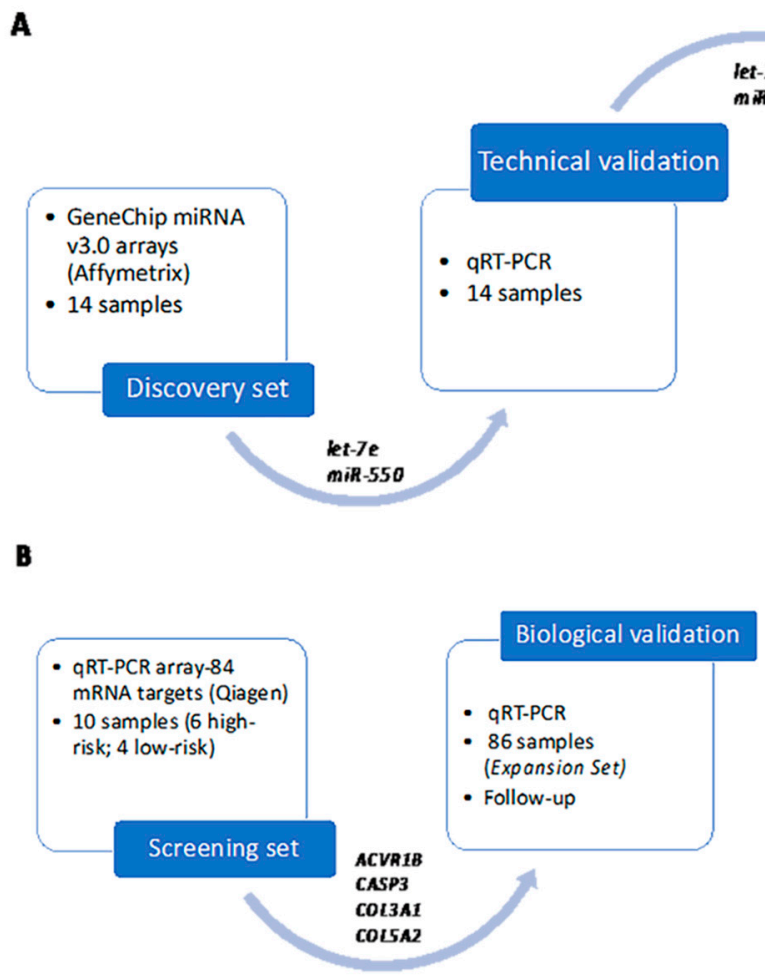

Figure 4. (A) study design to discover miRNAs differentially expressed with their technical and biological validation; (B) screening approach to demonstrate the clinical relevance of potential mRNA-let-7e targets. KIT and PDGFRA genotyping.

Among the 86 cases, 50 were sequenced using Sanger sequencing and the rest of the cases with NGS. DNA was isolated from 3- to 5- $\mu$ m sections of FFPE tissues. After deparaffinization, the tumor tissue was processed with the QIAamp DNA Investigator Kit (Qiagen) according to the manufacturer's 
instructions. Intronic primers were used to amplify exons 9, 11, 13 [48] and 17 [49] of KIT and exons 12 and 18 of PDGFRA [50] by PCR, as previously described in Martin et al. [8]. PCR products were bi-directionally sequenced in $\mathrm{F}$ and $\mathrm{R}$, with the specific intronic primers used in the amplification diluted to a work concentration of $3.2 \mu \mathrm{M}$. Sequencing was performed in an ABI 3130xl sequencer using the BigDye Terminator v3.1 (Applied Biosystems).

KIT and PDGFRA genotyping, by NGS, was performed using the GIST MASTR kit, following manufacturer's instructions (Multiplicom; Niel, Belgium). The assay generates a library of specific amplicons in two rounds of PCR followed by purification using Agencourt AMPure XP (Beckman Coulter, Beverly, MA, USA) and quantitation with PicoGreen, as described in Feliubadalo et al. [51].

Aligned sequences were visualized with Integrative Genomic Viewer Software 2.4.8 [52], and Variant calling was analyzed using Variant Studio 2.2 (Illumina; San Diego, CA, USA).

\subsubsection{Statistical Analysis}

Data analyses were performed with R v3.3.1 using R studio 0.99.486 and SPSS version 26 (IBM; Chicago, IL, USA). For categorical variables, frequency and percentages were calculated. For gene expression categorization, we calculate the optimal cutoff using ROC curves for their impact on progression and death. For time-to-event variables (i.e., relapse-free survival (RFS) and overall survival (OS)), we used Kaplan-Meier plots with a log-rank test to compare groups. For multivariate survival analysis, we implemented multivariate analysis with the variables that appeared to be significant in the univariate analysis, and the test was carried out according to the Cox proportional-hazard regression model with a backward variable selection. Linear regression was performed to correlate quantitative variables. All $p$-values reported were two-sided, and statistical significance was defined at $p<0.05$.

\subsubsection{Data Availability}

Raw data from microarray experiments are available in Gene Expression Omnibus (GEO) from NCBI: GSE156715156715.

\section{Conclusions}

In conclusion, our analysis from genomic profiling of miRNAs, in a homogeneous high-risk population of localized intestinal GIST, indicated the potential prognostic relevance in RFS for let-7e and 4 of its target genes: $A C V R 1 B, C A S P 3, C O L 3 A 1$, and COL5A2. This knowledge opens new options for prognostic biomarkers and potential therapeutic targets. The mechanistic link underlying their prognostic role is currently being investigated in our laboratory.

Supplementary Materials: The following are available online at http://www.mdpi.com/2072-6694/12/10/2979/s1, Table S1: Results of the mRNA differentially expressed in the target screening series. Table S2: Univariate analysis of metastatic cases treated with Imatinib $(n=56)$. Figure S1: Target miRNA expression in technical validation; Figure S2: Target miRNA expression in biological validation; Figure S3: Relapse-free survival according to let-7e.

Author Contributions: Conceptualization, J.M.-B. and J.A.L.-G. methodology, A.F.-S., D.S.M., M.D.S.-I., S.C.-F., A.G., J.A.L.-G., and J.M.-B.; validation, A.F.-S., J.A.L.-G., and J.M.-B.; formal analysis, A.F.-S., D.S.M., M.D.S.-I., A.G., J.A.L.-G., and J.M.-B. investigation, all the authors.; resources, J.A.L.-G. and J.M.-B.; data curation, all the authors; writing-original draft preparation, A.F.-S., J.A.L.-G., and J.M.-B.; writing-review and editing, all the authors.; visualization, all the authors.; supervision, J.A.L.-G. and J.M.-B.; project administration, J.M.-B.; funding acquisition, J.M.-B. and N.H. M.L.-A.; A.M.-M.; I.C.-G.; M.R.-C.; E.B.-A.; R.L.-R.; A.O.-H.; R.A.; A.P. methodology, validation, data curation, writing review, visualization. All authors have read and agreed to the published version of the manuscript.

Funding: The project was funded by the Instituto de Salud Carlos III (ISCIII (Carlos III Health Institute))-Fondo Europeo de Desarrollo Regional; FEDER (European Regional Development Fund (ERDF)), through a public competitive call (project reference PI15/01254; principal investigator Javier Martín Broto) and by the Consejería de la Salud-Junta de Andalucia-(Health Council-Regional Government of Andalusia)-Proyectos de investigación coordinados 2016, through a competitive public call (project reference PC-0537-2016-0537; principal investigator Nadia Hindi).

Conflicts of Interest: David S. Moura reports institutional research grants from PharmaMar, Eisai, Immix BioPharma, and Novartis outside the submitted work; travel support from PharmaMar, Eisai, Celgene, Bayer, 
and Pfizer. Nadia Hindi reports grants, personal fees and non-financial support from PharmaMar, personal fees from Lilly, grants from Eisai, and Novartis, outside the submitted work and research funding for clinical studies (institutional) from PharmaMar, Eli Lilly and Company, AROG, Bayer, Eisai, Lixte, Karyopharm, Deciphera, GSK, Novartis, Blueprint, Nektar, Forma, Amgen, and Daichii-Sankyo. Andres Poveda reports consulting or advisory role fees from PharmaMar, AstraZeneca, Roche, Clovis Oncology, and Tesaro, and travel support from PharmaMar. Javier Martin-Broto reports research grants from PharmaMar, Eisai, Immix BioPharma, and Novartis outside the submitted work; honoraria for advisory board participation and expert testimony from PharmaMar, Eli Lilly and Company, Bayer, and Eisai; and research funding for clinical studies (institutional) from PharmaMar, Eli Lilly and Company, AROG, Bayer, Eisai, Lixte, Karyopharm, Deciphera, GSK, Novartis, Blueprint, Nektar, Forma, Amgen, and Daichii-Sankyo. All the other authors report no conflicts of interest. On the other hand, the funders had no role in the design of the study; in the collection, analyses, or interpretation of data; in the writing of the manuscript, or in the decision to publish the result.

\section{Appendix A. mRNA Targets of let-7e}

NM_004302 ACVR1B Activin A receptor, type IB

NM_007037 ADAMTS8 ADAM metallopeptidase with thrombospondin type 1 motif, 8

NM_138578 BCL2L1 BCL2-like 1

NM_001728 BSG Basigin (OK blood group)

NM_014670 BZW1 Basic leucine zipper and W2 domains 1

NM_004346 CASP3 Caspase 3, apoptosis-related cysteine peptidase

NM_001237 CCNA2 Cyclin A2

NM_053056 CCND1 Cyclin D1

NM_001759 CCND2 Cyclin D2

NM_014711 CCP110 Centriolar coiled coil protein 110kDa

NM_001789 CDC25A Cell division cycle 25 homolog A (S. pombe)

NM_004359 CDC34 Cell division cycle 34 homolog (S. cerevisiae)

NM_001259 CDK6 Cyclin-dependent kinase 6

NM_025009 CEP135 Centrosomal protein 135kDa

NM_001273 CHD4 Chromodomain helicase DNA binding protein 4

NM_004898 CLOCK Clock homolog (mouse)

NM_000089 COL1A2 Collagen, type I, alpha 2

NM_000090 COL3A1 Collagen, type III, alpha 1

NM_000393 COL5A2 Collagen, type V, alpha 2

NM_007242 DDX19B DEAD (Asp-Glu-Ala-As) box polypeptide 19B

NM_177438 DICER1 Dicer 1, ribonuclease type III

NM_004417 DUSP1 Dual specificity phosphatase 1

NM_005225 E2F1 E2F transcription factor 1

NM_004091 E2F2 E2F transcription factor 2

NM_017629 AGO4 Eukaryotic translation initiation factor 2C, 4

NM_015123 FRMD4B FERM domain containing 4B

NM_001482 GATM Glycine amidinotransferase (L-arginine:glycine amidinotransferase)

NM_001001557 GDF6 Growth differentiation factor 6

NM_024312 GNPTAB N-acetylglucosamine-1-phosphate transferase, alpha and beta subunits

NM_017902 HIF1AN Hypoxia inducible factor 1, alpha subunit inhibitor

NM_005338 HIP1 Huntingtin interacting protein 1

NM_152739 HOXA9 Homeobox A9

NM_002176 IFNB1 Interferon, beta 1, fibroblast

NM_006546 IGF2BP1 Insulin-like growth factor 2 mRNA binding protein 1

NM_006547 IGF2BP3 Insulin-like growth factor 2 mRNA binding protein 3 
NM_003640 IKBKAP Inhibitor of kappa light polypeptide gene enhancer in B-cells, kinase complex-associated protein

NM_002188 IL13 Interleukin 13

NM_000600 IL6 Interleukin 6 (interferon, beta 2)

NM_001023570 IQCB1 IQ motif containing B1

NM_000212 ITGB3 Integrin, beta 3 (platelet glycoprotein IIIa, antigen CD61)

NM_002776 KLK10 Kallikrein-related peptidase 10

NM_002774 KLK6 Kallikrein-related peptidase 6

NM_004985 KRAS V-Ki-ras2 Kirsten rat sarcoma viral oncogene homolog

NM_024674 LIN28A Lin-28 homolog A (C. elegans)

NM_014813 LRIG2 Leucine-rich repeats and immunoglobulin-like domains 2

NM_153377 LRIG3 Leucine-rich repeats and immunoglobulin-like domains 3

NM_003618 MAP4K3 Mitogen-activated protein kinase kinase kinase kinase 3

NM_001315 MAPK14 Mitogen-activated protein kinase 14

NM_002748 MAPK6 Mitogen-activated protein kinase 6

NM_002750 MAPK8 Mitogen-activated protein kinase 8

NM_002467 MYC V-myc myelocytomatosis viral oncogene homolog (avian)

NM_005378 MYCN V-myc myelocytomatosis viral related oncogene, neuroblastoma derived (avian)

NM_181659 NCOA3 Nuclear receptor coactivator 3

NM_000268 NF2 Neurofibromin 2 (merlin)

NM_017595 NKIRAS2 NFKB inhibitor interacting Ras-like 2

NM_153240 NPHP3 Nephronophthisis 3 (adolescent)

NM_003269 NR2E1 Nuclear receptor subfamily 2, group E, member 1

NM_002524 NRAS Neuroblastoma RAS viral (v-ras) oncogene homolog

NM_015393 PARM1 Prostate androgen-regulated mucin-like protein 1

NM_006195 PBX3 Pre-B-cell leukemia homeobox 3

NM_017990 PDPR Pyruvate dehydrogenase phosphatase regulatory subunit

NM_015715 PLA2G3 Phospholipase A2, group III

NM_005761 PLXNC1 Plexin C1

NM_002717 PPP2R2A Protein phosphatase 2, regulatory subunit B, alpha

NM_182907 PRDM1 PR domain containing 1, with ZNF domain

NM_006267 RANBP2 RAN binding protein 2

NM_006909 RASGRF2 Ras protein-specific guanine nucleotide-releasing factor 2

NM_018211 RAVER2 Ribonucleoprotein, PTB-binding 2

NM_002901 RCN1 Reticulocalbin 1, EF-hand calcium binding domain

NM_020436 SALL4 Sal-like 4 (Drosophila)

NM_000617 SLC11A2 Solute carrier family 11 (proton-coupled divalent metal ion transporters), member 2

NM_006306 SMC1A Structural maintenance of chromosomes 1A

NM_080867 SOCS4 Suppressor of cytokine signaling 4

NM_004612 TGFBR1 Transforming growth factor, beta receptor 1

NM_138554 TLR4 Toll-like receptor 4

NM_001039111 TRIM71 Tripartite motif containing 71

NM_007275 TUSC2 Tumor suppressor candidate 2

NM_152896 UHRF2 Ubiquitin-like with PHD and ring finger domains 2

NM_182488 USP12 Ubiquitin specific peptidase 12

NM_032582 USP32 Ubiquitin specific peptidase 32 
NM_014023 WDR37 WD repeat domain 37

NM_005430 WNT1 Wingless-type MMTV integration site family, member 1

NM_014872 ZBTB5 Zinc finger and BTB domain containing 5

NM_015346 ZFYVE26 Zinc finger, FYVE domain containing 26

NM_001101 ACTB Actin, beta

NM_004048 B2M Beta-2-microglobulin

NM_002046 GAPDH Glyceraldehyde-3-phosphate dehydrogenase

NM_000194 HPRT1 Hypoxanthine phosphoribosyltransferase 1

NM_001002 RPLP0 Ribosomal protein, large, P0

SA_00105 HGDC Human Genomic DNA Contamination

SA_00104 RTC Reverse Transcription Control

SA_00104 RTC Reverse Transcription Control

SA_00104 RTC Reverse Transcription Control

SA_00103 PPC Positive PCR Control

SA_00103 PPC Positive PCR Control

SA_00103 PPC Positive PCR Control

\section{References}

1. Miettinen, M.; Lasota, J. Gastrointestinal stromal tumors: Pathology and prognosis at different sites. Semin. Diagn. Pathol. 2006, 23, 70-83. [CrossRef] [PubMed]

2. Verweij, J.; Casali, P.G.; Zalcberg, J.; LeCesne, A.; Reichardt, P.; Blay, J.Y.; Issels, R.; van Oosterom, A.; Hogendoorn, P.C.; Van Glabbeke, M.; et al. Progression-free survival in gastrointestinal stromal tumours with high-dose imatinib: Randomised trial. Lancet 2004, 364, 1127-1134. [CrossRef]

3. Demetri, G.D.; van Oosterom, A.T.; Garrett, C.R.; Blackstein, M.E.; Shah, M.H.; Verweij, J.; McArthur, G.; Judson, I.R.; Heinrich, M.C.; Morgan, J.A.; et al. Efficacy and safety of sunitinib in patients with advanced gastrointestinal stromal tumour after failure of imatinib: A randomised controlled trial. Lancet 2006, 368, 1329-1338. [CrossRef]

4. Demetri, G.D.; Reichardt, P.; Kang, Y.K.; Blay, J.Y.; Rutkowski, P.; Gelderblom, H.; Hohenberger, P.; Leahy, M.; von Mehren, M.; Joensuu, H.; et al. Efficacy and safety of regorafenib for advanced gastrointestinal stromal tumours after failure of imatinib and sunitinib (GRID): An international, multicentre, randomised, placebo-controlled, phase 3 trial. Lancet 2013, 381, 295-302. [CrossRef]

5. Joensuu, H.; Eriksson, M.; Sundby Hall, K.; Reichardt, A.; Hartmann, J.T.; Pink, D.; Ramadori, G.; Hohenberger, P.; Al-Batran, S.E.; Schlemmer, M.; et al. Adjuvant Imatinib for High-Risk GI Stromal Tumor: Analysis of a Randomized Trial. J. Clin. Oncol. Off. J. Am. Soc. Clin. Oncol. 2016, 34, $244-250$. [CrossRef]

6. Joensuu, H.; Vehtari, A.; Riihimaki, J.; Nishida, T.; Steigen, S.E.; Brabec, P.; Plank, L.; Nilsson, B.; Cirilli, C.; Braconi, C.; et al. Risk of recurrence of gastrointestinal stromal tumour after surgery: An analysis of pooled population-based cohorts. Lancet Oncol. 2012, 13, 265-274. [CrossRef]

7. Wardelmann, E.; Losen, I.; Hans, V.; Neidt, I.; Speidel, N.; Bierhoff, E.; Heinicke, T.; Pietsch, T.; Buttner, R.; Merkelbach-Bruse, S. Deletion of Trp-557 and Lys-558 in the juxtamembrane domain of the c-kit protooncogene is associated with metastatic behavior of gastrointestinal stromal tumors. Int. J. Cancer 2003, 106, 887-895. [CrossRef] [PubMed]

8. Martin, J.; Poveda, A.; Llombart-Bosch, A.; Ramos, R.; Lopez-Guerrero, J.A.; Garcia del Muro, J.; Maurel, J.; Calabuig, S.; Gutierrez, A.; Gonzalez de Sande, J.L.; et al. Deletions affecting codons 557-558 of the c-KIT gene indicate a poor prognosis in patients with completely resected gastrointestinal stromal tumors: A study by the Spanish Group for Sarcoma Research (GEIS). J. Clin. Oncol. Off. J. Am. Soc. Clin. Oncol. 2005, 23, 6190-6198. [CrossRef] [PubMed] 
9. Wozniak, A.; Rutkowski, P.; Schoffski, P.; Ray-Coquard, I.; Hostein, I.; Schildhaus, H.U.; Le Cesne, A.; Bylina, E.; Limon, J.; Blay, J.Y.; et al. Tumor genotype is an independent prognostic factor in primary gastrointestinal stromal tumors of gastric origin: A european multicenter analysis based on ConticaGIST. Clin. Cancer Res. Off. J. Am. Assoc. Cancer Res. 2014, 20, 6105-6116. [CrossRef]

10. Broto, M.J.; Calabuig, S.; Rubio, J.; Gutierrez, A.; Duran, J.; Garcia, F.; Martinez-Trufero, J.; Maurel, J.; Del Muro, G.; Cruz, J.; et al. Integrating genotype in risk classification for GIST recurrence. A Spanish Group for Sarcoma Research (GEIS) study. Ann. Oncol. 2014, 25 (Suppl. 4), iv494-iv510. [CrossRef]

11. Sanchez, I.; Betsou, F.; Culot, B.; Frasquilho, S.; McKay, S.C.; Pericleous, S.; Smith, C.; Thomas, G.; Mathieson, W. RNA and microRNA Stability in PAXgene-Fixed Paraffin-Embedded Tissue Blocks After Seven Years' Storage. Am. J. Clin. Pathol. 2018, 149, 536-547. [CrossRef] [PubMed]

12. Bussing, I.; Slack, F.J.; Grosshans, H. let-7 microRNAs in development, stem cells and cancer. Trends Mol. Med. 2008, 14, 400-409. [CrossRef] [PubMed]

13. Ma, J.; Zhan, Y.; Xu, Z.; Li, Y.; Luo, A.; Ding, F.; Cao, X.; Chen, H.; Liu, Z. ZEB1 induced miR-99b/let-7e/miR-125a cluster promotes invasion and metastasis in esophageal squamous cell carcinoma. Cancer Lett. 2017, 398, 37-45. [CrossRef]

14. Zhang, Z.; Li, Y.; Huang, L.; Xiao, Q.; Chen, X.; Zhong, J.; Chen, Y.; Yang, D.; Han, Z.; Shu, Y.; et al. Let-7a suppresses macrophage infiltrations and malignant phenotype of Ewing sarcoma via STAT3/NF-kappaB positive regulatory circuit. Cancer Lett. 2016, 374, 192-201. [CrossRef]

15. Schultz, J.; Lorenz, P.; Gross, G.; Ibrahim, S.; Kunz, M. MicroRNA let-7b targets important cell cycle molecules in malignant melanoma cells and interferes with anchorage-independent growth. Cell Res. 2008, 18, 549-557. [CrossRef]

16. Calatayud, D.; Dehlendorff, C.; Boisen, M.K.; Hasselby, J.P.; Schultz, N.A.; Werner, J.; Immervoll, H.; Molven, A.; Hansen, C.P.; Johansen, J.S. Tissue MicroRNA profiles as diagnostic and prognostic biomarkers in patients with resectable pancreatic ductal adenocarcinoma and periampullary cancers. Biomark. Res. 2017, 5, 8. [CrossRef]

17. Chirshev, E.; Oberg, K.C.; Ioffe, Y.J.; Unternaehrer, J.J. Let-7 as biomarker, prognostic indicator, and therapy for precision medicine in cancer. Clin. Transl. Med. 2019, 8, 24. [CrossRef]

18. Lee, Y.S.; Dutta, A. The tumor suppressor microRNA let-7 represses the HMGA2 oncogene. Genes Dev. 2007, 21, 1025-1030. [CrossRef]

19. Sun, X.; Xu, C.; Tang, S.C.; Wang, J.; Wang, H.; Wang, P.; Du, N.; Qin, S.; Li, G.; Xu, S.; et al. Let-7c blocks estrogen-activated Wnt signaling in induction of self-renewal of breast cancer stem cells. Cancer Gene Ther. 2016, 23, 83-89. [CrossRef] [PubMed]

20. Song, H.; Zhang, Y.; Liu, N.; Zhang, D.; Wan, C.; Zhao, S.; Kong, Y.; Yuan, L. Let-7b inhibits the malignant behavior of glioma cells and glioma stem-like cells via downregulation of E2F2. J. Physiol. Biochem. 2016, 72, 733-744. [CrossRef]

21. Ning, Y.; Xu, M.; Cao, X.; Chen, X.; Luo, X. Inactivation of AKT, ERK and NF-kappaB by genistein derivative, 7-difluoromethoxyl-5,4'-di-n-octylygenistein, reduces ovarian carcinoma oncogenicity. Oncol. Rep. 2017, 38, 949-958. [CrossRef] [PubMed]

22. Curtale, G.; Renzi, T.A.; Mirolo, M.; Drufuca, L.; Albanese, M.; De Luca, M.; Rossato, M.; Bazzoni, F.; Locati, M. Multi-Step Regulation of the TLR4 Pathway by the miR-125a 99b let-7e Cluster. Front. Immunol. 2018, 9, 2037. [CrossRef] [PubMed]

23. Mitra, D.; Das, P.M.; Huynh, F.C.; Jones, F.E. Jumonji/ARID1 B (JARID1B) protein promotes breast tumor cell cycle progression through epigenetic repression of microRNA let-7e. J. Biol. Chem. 2011, 286, 40531-40535. [CrossRef] [PubMed]

24. Sun, H.; Ding, C.; Zhang, H.; Gao, J. Let7 miRNAs sensitize breast cancer stem cells to radiationinduced repression through inhibition of the cyclin D1/Akt1/Wnt1 signaling pathway. Mol. Med. Rep. 2016, 14, 3285-3292. [CrossRef]

25. Li, Y.; Zhang, X.; Chen, D.; Ma, C. Let-7a suppresses glioma cell proliferation and invasion through TGF- $\beta /$ Smad3 signaling pathway by targeting HMGA2. Tumour Biol. J. Int. Soc. Oncodev. Biol. Med. 2016, 37, 8107-8119. [CrossRef] [PubMed]

26. Wu, A.; Wu, K.; Li, J.; Mo, Y.; Lin, Y.; Wang, Y.; Shen, X.; Li, S.; Li, L.; Yang, Z. Let-7a inhibits migration, invasion and epithelial-mesenchymal transition by targeting HMGA2 in nasopharyngeal carcinoma. J. Transl. Med. 2015, 13, 105. [CrossRef] [PubMed] 
27. Tvingsholm, S.A.; Hansen, M.B.; Clemmensen, K.K.B.; Brix, D.M.; Rafn, B.; Frankel, L.B.; Louhimo, R.; Moreira, J.; Hautaniemi, S.; Gromova, I.; et al. Let-7 microRNA controls invasion-promoting lysosomal changes via the oncogenic transcription factor myeloid zinc finger-1. Oncogenesis 2018, 7, 14. [CrossRef]

28. Ding, C.; Yu, H.; Shi, C.; Shi, T.; Qin, H.; Cui, Y. MiR-let-7e inhibits invasion and magration and regulates HMGB1 expression in papillary thyroid carcinoma. Biomed. Pharmacother. Biomed. Pharmacother. 2019, 110, 528-536. [CrossRef]

29. Yuan, L.; Shu, B.; Chen, L.; Qian, K.; Wang, Y.; Qian, G.; Zhu, Y.; Cao, X.; Xie, C.; Xiao, Y.; et al. Overexpression of COL3A1 confers a poor prognosis in human bladder cancer identified by co-expression analysis. Oncotarget 2017, 8, 70508-70520. [CrossRef] [PubMed]

30. Qiu, F.; Sun, R.; Deng, N.; Guo, T.; Cao, Y.; Yu, Y.; Wang, X.; Zou, B.; Zhang, S.; Jing, T.; et al. miR-29a/b enhances cell migration and invasion in nasopharyngeal carcinoma progression by regulating SPARC and COL3A1 gene expression. PLoS ONE 2015, 10, e0120969. [CrossRef]

31. Meng, X.Y.; Shi, M.J.; Zeng, Z.H.; Chen, C.; Liu, T.Z.; Wu, Q.J.; Li, S. The Role of COL5A2 in Patients with Muscle-Invasive Bladder Cancer: A Bioinformatics Analysis of Public Datasets Involving 787 Subjects and 29 Cell Lines. Front. Oncol. 2018, 8, 659. [CrossRef] [PubMed]

32. Chen, H.; Liu, W.; Zhong, L.; Liao, D.; Zhang, R.; Kang, T.; Wu, Y. NKX2-2 Suppresses Osteosarcoma Metastasis and Proliferation by Downregulating Multiple Target Genes. J. Cancer 2018, 9, 3067-3077. [CrossRef] [PubMed]

33. Li, L.; Liu, Y.; Guo, Y.; Liu, B.; Zhao, Y.; Li, P.; Song, F.; Zheng, H.; Yu, J.; Song, T.; et al. Regulatory MiR-148a-ACVR1/BMP circuit defines a cancer stem cell-like aggressive subtype of hepatocellular carcinoma. Hepatology 2015, 61, 574-584. [CrossRef] [PubMed]

34. Valer, J.A.; Sanchez-de-Diego, C.; Pimenta-Lopes, C.; Rosa, J.L.; Ventura, F. ACVR1 Function in Health and Disease. Cells 2019, 8. [CrossRef]

35. Liu, P.F.; Hu, Y.C.; Kang, B.H.; Tseng, Y.K.; Wu, P.C.; Liang, C.C.; Hou, Y.Y.; Fu, T.Y.; Liou, H.H.; Hsieh, I.C.; et al. Expression levels of cleaved caspase-3 and caspase-3 in tumorigenesis and prognosis of oral tongue squamous cell carcinoma. PLoS ONE 2017, 12, e0180620. [CrossRef] [PubMed]

36. O’Donovan, N.; Crown, J.; Stunell, H.; Hill, A.D.; McDermott, E.; O’Higgins, N.; Duffy, M.J. Caspase 3 in breast cancer. Clin. Cancer Res. Off. J. Am. Assoc. Cancer Res. 2003, 9, 738-742.

37. Winter, R.N.; Kramer, A.; Borkowski, A.; Kyprianou, N. Loss of caspase-1 and caspase-3 protein expression in human prostate cancer. Cancer Res. 2001, 61, 1227-1232. [PubMed]

38. Ryoo, H.D.; Bergmann, A. The role of apoptosis-induced proliferation for regeneration and cancer. Cold Spring Harb. Perspect. Biol. 2012, 4, a008797. [CrossRef]

39. Ravegnini, G.; Sammarini, G.; Nannini, M.; Pantaleo, M.A.; Biasco, G.; Hrelia, P.; Angelini, S. Gastrointestinal stromal tumors (GIST): Facing cell death between autophagy and apoptosis. Autophagy 2017, 13, $452-463$. [CrossRef]

40. Grigoriev, M.Y.; Pozharissky, K.M.; Hanson, K.P.; Imyanitov, E.N.; Zhivotovsky, B. Expression of caspase-3 and -7 does not correlate with the extent of apoptosis in primary breast carcinomas. Cell Cycle 2002, 1, 337-342. [CrossRef] [PubMed]

41. Ma, Y.Y.; Yu, S.; He, X.J.; Xu, Y.; Wu, F.; Xia, Y.J.; Guo, K.; Wang, H.J.; Ye, Z.Y.; Zhang, W.; et al. Involvement of c-KIT mutation in the development of gastrointestinal stromal tumors through proliferation promotion and apoptosis inhibition. Oncotargets Ther. 2014, 7, 637-643. [CrossRef]

42. Schwamb, B.; Pick, R.; Fernandez, S.B.; Volp, K.; Heering, J.; Dotsch, V.; Bosser, S.; Jung, J.; Beinoraviciute-Kellner, R.; Wesely, J.; et al. FAM96A is a novel pro-apoptotic tumor suppressor in gastrointestinal stromal tumors. Int. J. Cancer 2015, 137, 1318-1329. [CrossRef] [PubMed]

43. Gits, C.M.; van Kuijk, P.F.; Jonkers, M.B.; Boersma, A.W.; van Ijcken, W.F.; Wozniak, A.; Sciot, R.; Rutkowski, P.; Schöffski, P.; Taguchi, T.; et al. MiR-17-92 and miR-221/222 cluster members target KIT and ETV1 in human gastrointestinal stromal tumours. Br. J. Cancer 2013, 109, 1625-1635. [CrossRef] [PubMed]

44. Ihle, M.A.; Trautmann, M.; Kuenstlinger, H.; Huss, S.; Heydt, C.; Fassunke, J.; Wardelmann, E.; Bauer, S.; Schildhaus, H.U.; Buettner, R.; et al. miRNA-221 and miRNA-222 induce apoptosis via the KIT/AKT signalling pathway in gastrointestinal stromal tumours. Mol. Oncol. 2015, 9, 1421-1433. [CrossRef] [PubMed] 
45. Moura, D.S.; Ramos, R.; Fernandez-Serra, A.; Serrano, T.; Cruz, J.; Alvarez-Alegret, R.; Ortiz-Duran, R.; Vicioso, L.; Gomez-Dorronsoro, M.L.; Garcia Del Muro, X.; et al. Gene expression analyses determine two different subpopulations in KIT-negative GIST-like (KNGL) patients. Oncotarget 2018, 9, 17576-17588. [CrossRef] [PubMed]

46. Chen, Y.; Wang, X. miRDB: An online database for prediction of functional microRNA targets. Nucleic Acids Res. 2019, 48, D127-D131. [CrossRef]

47. Liu, W.; Wang, X. Prediction of functional microRNA targets by integrative modeling of microRNA binding and target expression data. Genome Biol. 2019, 20, 18. [CrossRef]

48. Lasota, J.; Wozniak, A.; Sarlomo-Rikala, M.; Rys, J.; Kordek, R.; Nassar, A.; Sobin, L.H.; Miettinen, M. Mutations in exons 9 and 13 of KIT gene are rare events in gastrointestinal stromal tumors. A study of 200 cases. Am. J. Pathol. 2000, 157, 1091-1095. [CrossRef]

49. Corless, C.L.; McGreevey, L.; Haley, A.; Town, A.; Heinrich, M.C. KIT mutations are common in incidental gastrointestinal stromal tumors one centimeter or less in size. Am. J. Pathol. 2002, 160, 1567-1572. [CrossRef]

50. Heinrich, M.C.; Corless, C.L.; Duensing, A.; McGreevey, L.; Chen, C.J.; Joseph, N.; Singer, S.; Griffith, D.J.; Haley, A.; Town, A.; et al. PDGFRA activating mutations in gastrointestinal stromal tumors. Science 2003, 299, 708-710. [CrossRef]

51. Feliubadalo, L.; Lopez-Doriga, A.; Castellsague, E.; del Valle, J.; Menendez, M.; Tornero, E.; Montes, E.; Cuesta, R.; Gomez, C.; Campos, O.; et al. Next-generation sequencing meets genetic diagnostics: Development of a comprehensive workflow for the analysis of BRCA1 and BRCA2 genes. Eur. J. Hum. Genet. EJHG 2013, 21, 864-870. [CrossRef] [PubMed]

52. Thorvaldsdottir, H.; Robinson, J.T.; Mesirov, J.P. Integrative Genomics Viewer (IGV): High-performance genomics data visualization and exploration. Brief. Bioinform. 2013, 14, 178-192. [CrossRef] [PubMed]

Publisher's Note: MDPI stays neutral with regard to jurisdictional claims in published maps and institutional affiliations. 